\title{
Peran Reserse Kriminal Umum sebagai Penyelidik Tindak Pidana Curat dan Curas (Studi di Polrestabes Medan)
}

\section{The Role of General Criminal Agency as Investigator in the Crime of Theft and Robbery (Study of Polrestabes Medan)}

\author{
Hardiyanto1), Marlina2) \& Muaz Zul ${ }^{3)}$ \\ 1) Program Pasca Sarjana, Magister Ilmu Hukum, Universitas Medan Area, Indonesia \\ 2) Fakultas Hukum Universitas Sumatera Utara, Indonesia \\ 3) Fakultas Hukum Universitas Medan Area, Indonesia
}

\begin{abstract}
Abstrak
Artikel ini membahas permasalahan mengenai faktor penyebab peningkatan tindak pidana pencurian dengan pemberatan dan kekerasan di Medan, Bagaimana peran Reserse Kriminal Umum Polrestabes Medan dan apa hambatan dalam menanggulangi tindak pidana pencurian dengan pemberatan dan kekerasan di Medan. Penelitian ini mempergunakan metode penelitian hukum yuridis normatif, dengan analisis kualitatif. Data yang digunakan adalah data sekunder dengan mempergunakan sumber hukum primer. Hasil yang didapat dalam penelitian ini adalah bahwa penyebab terjadinya kenaikan tingkat tindak pidana pencurian dengan pemberatan dan kekerasan adalah faktor internal dan eksternal pelaku kejahatan. Reserse Kriminal Umum Polrestabes Medan memiliki peran sebagai penyelidik dan penyidik dalam tindak pidana pencurian dengan pemberatan dan kekerasan yang dapat mempergunakan kewenangan yang diberikan oleh KUHAP dan undang-undang kepolisian. Hambatan yang didapat oleh reserse kriminal umm dapat dikategorikan menjadi hambatan yuridis dan hambaan non yuridis.

Kata Kunci: Curat, Curas, Kriminal, Reserse Kriminal Umum.
\end{abstract}

\begin{abstract}
This article discusses the problems regarding the factors causing the increase in criminal by theft robbery in Medan, what is the role of the General Criminal Agency of the Polerstabes Medan and what are the barriers Sin dealing with theft and robbery in the city of Medan. This study uses normative juridical legal research methods, with qualitative analysis. The data used are secondary data using primary legal sources. The results obtained in this study are that the cause of the increase in the level of criminal acts of theft and robbery is internal and external factors of the perpetrators of crime. General Criminal Agency Polrestabes Medan has a role as an investigator and investigator in criminal acts of theft and robbery that can use the authority given by the Criminal Procedure Code and police law. Obstacles obtained by criminal investigators can be categorized as barriers to juridical and non-juridical servitude.

Keywords: Theft, Robbery, Crime, General Criminal Agency.
\end{abstract}

How to Cite: Hardiyanto, Marlina \& Muazzul. (2020). Peran Reserse Kriminal Umum sebagai Penyelidik Tindak Pidana Curat dan Curas (Studi di Polrestabes Medan). ARBITER: Jurnal Ilmiah Magister Hukum, 1(1) 2020: 170-180, 


\section{PENDAHULUAN}

Penegakan hukum di Indonesia perlu adanya aparatur penegak hukum yang handal, beribawa, penuh pengabdian, cerdas, taat hukum dan berwawasan luas, supaya terciptanya aparatur penegak hukum yang disenangi dan disegani oleh masyarakat, terutama bagi penegak hukum di tubuh kepolisian negara Indonesia. Pengertian penegakan hukum adalah suatu proses untuk mewujudkan keinginan-keinginan hukum menjadi kenyataan, yang disebut sebagai keinginan-keinginan hukum disini tidak lain adalah pikiran-pikiran badan pembuat undang-undang yang dirumuskan dalam peraturan itu (Marmosudjono, 1989; 12).

Tindak kejahatan yang dilakukan oleh seorang atau kelompok secara bersama-sama dilatar belakangi masalah klasik seperti kesulitan ekonomi, rendahnya tingkat pendidikan,meningkatnya pengangguran, kurangnya kesadaran hukum, mengendurnya ikatan keluarga, pengaruh teman dalam pergaulan, hukumannya terlalu ringan, adanya kesempatan atau kelengahan dari korban, arus globalisasi dan pertambahan jumlah penduduk serta pengaruh narkotika. Hal tersebut memicu terjadinya tindak pidana Pencurian Dengan Kekerasan/Curas (Pasal 365 KUHP), Pencurian Dengan Pemberatan/Curat (Pasal 363 KUHP), dan Pencurian Kendaraan/Curan (Pasal 362, 363, 365 KUHP).

Berikut Data Kejahatan Pencurian di Kota Medan tahun 2014-2017:

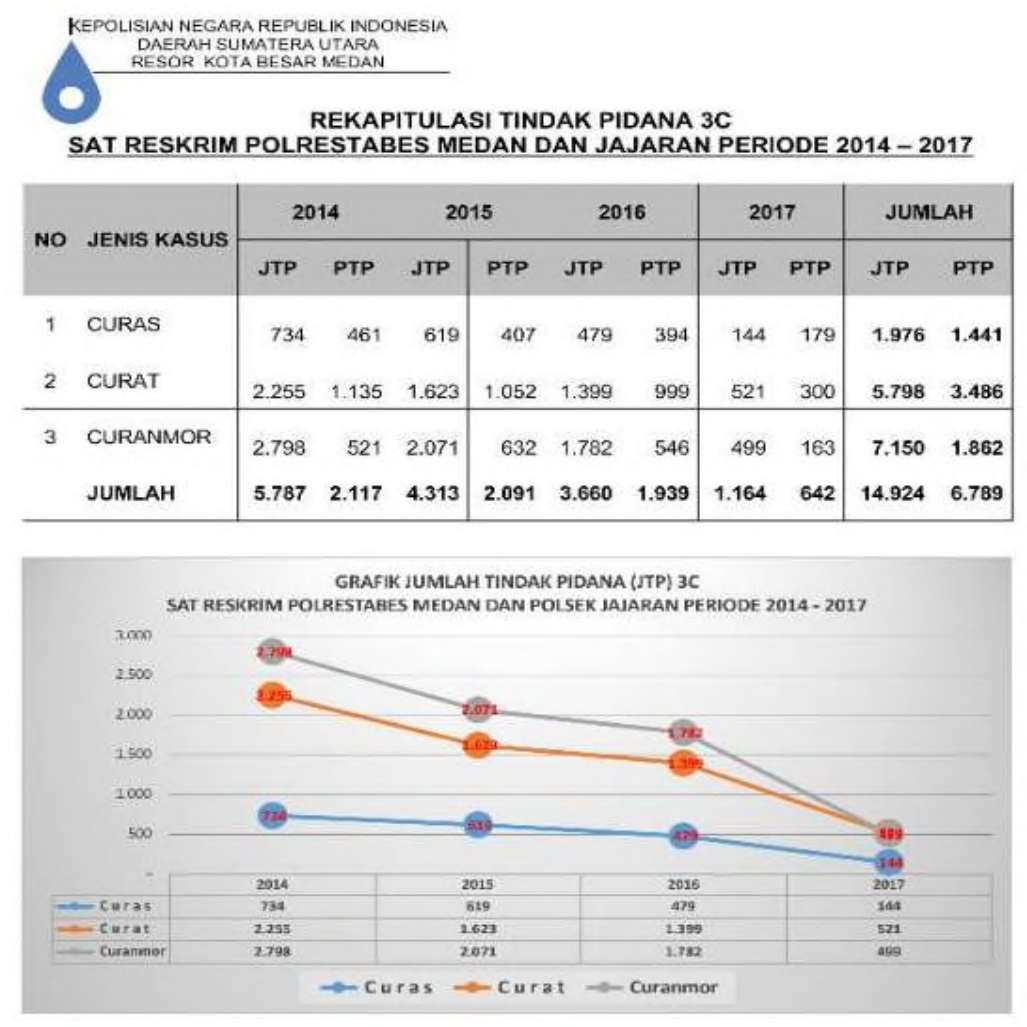

Pencurian Dengan Kekerasan Dalam istilah awam, pencurian dengan kekerasan sering di sebut perampokan. Pada pencurian dengan kekerasan yang ada pada Pasal 365, yaitu menggunakan upaya kekerasan dan atau ancaman kekerasan. Maksudnya adalah 
Hardiyanto, Marlina \& Muazzul, Peran Reserse Kriminal Umum sebagai Penyelidik Tindak Pidana...

untuk mempersiapkan, memudahkan pelaksanaan pencurian dan seterusnya. Artinya kekerasan atau ancaman kekerasan itu mempunyai peranan atau hubungan terhadap kejahatan pokok (pencurian). Kasus pencurian bisa di sebut pencurian dengan kekerasan bila sudah memenuhi unsur-unsur sebagai berikut:

1) Memaksa orang lain dengan ancaman atau dengan kekerasan;

2) Supaya orang itu memberikan sesuatu barang yang sama sekali atau sebagian milik orang itu atau milik orang lain;

3) Supaya orang itu membuat utang atau menhapus utang;

4) Dengan maksud agar menguntungkan dirinya sendiri atau diri prang lain dengan melawan hukum.

Pencurian adalah suatu tindak pidana yang dapat dilakukan berdasarkan dengan kekerasan ataupun dengan pemberatan. Tindak pidana pencurian tersebut dikenal dengan istilah 3C (Curas, Curat, Curan). Pada tahun 2015 Kepolisian Daerah Sumatera Utara menangani 593 kasus pencurian dengan kekerasan (Curas), 3.332 kasus pencurian dengan pemberatan (CURAT) dan 2.910 kasus pencurian kendaraan (CURAN) (Tribun News, 24/07/2015).

Berikut beberapa contoh Kasus Tindak Pidana Pencurian dengan Pemberatan yang terjadi di Kota Medan (Data dari Unit Reskrim Polrestabes Medan, 2016):

1) Pada tanggal 07 Juli 2016 terjadi tindak pidana pencurian dengan pemberatan yang berlokasi di jalan Cinta Karya No 82A Sari Rejo Polonia Medan dengan Korban bernama Ahyan,S.Sos,MM. yang dilakukan oleh Pelaku bernama Gaga Suhendra als Gaga yang berprofesi penarik becak bermotor, adapun barang yang dicuri adalah satu buah unit mobil dan beberapa buah BPKB mobil dan Sepeda Motor, Sertifikat tanah, Satu buah senjata api, Perhiasan yang bernilai sekitar Rp.500.000.000, 25 unit jam tangan, Surat-surat berharga ( ijasah kepolisiaan dan buku tabungan) yang secara keseluruhan korban menderita kerugian Rp.1.500.000.000 ( satu miliar lima ratus juta rupiah)

2) Pada hari minggu tanggal 18 september 2016 terjadi tindak pidana pencurian dengan kekerasan yang diatur dalam Pasal 340 subs Pasal 338 subs Pasal 365 ayat 3 KUHP dan Pasal 80 ayat 3 Undang-Undang Nomor 35 tahun 2014 tentang perubahan atas Undang-Undang Nomor 23 tahun 2002 tentang Perlindungan Anak, yang terjadi di Pasar IX PTPN II Desa Bandar Klippa Kec. Percut Sei tuan dengan seorang Korban yang bernama Siti Habibah yang meninggal setelah ditemukan tenggelam. Adapun Pelaku adalah Ismail berusia 24 tahun.

3) Pada tanggal 03 September 2016 telah terjadi Tindak pidana Pencurian dengan kekerasan dan pemerkosaan atau perbatan cabul dengan seseorang dalam keadaan tidak berdaya (Pasal 365 ayat 2 Jo Pasal 285 atau Pasal 293 KUHP) yang berlokasi di Jalan Sei Glugur Rimbun Kec. Kutalinbaru dengan korban bernama Mia Audianingsih, yang berumur 18 tahun dengan tersangka Edy suwito berusia 42 Tahun.

Berdasarkan beberapa kasus diatas, tindak pidana pencurian dengan pemberatan dan kekerasan merupakan sebuah kejahatan yang sering terjadi dan harus mendapatkan penanggulangan serta pencegahan yang tepat supaya masyarakat dapat kondusif. 
Kebijakan penanggulangan tindak pidana CURAS, CURAT dengan menggunakan sarana penal oleh beberapa pakar kriminologi disebut juga dengan cara represif. Tindakan represif menitik beratkan pada upaya pemberantasan/penindasan/penumpasan sesudah kejahatan terjadi yaitu dengan dijatuhkannya sanksi pidana, dimana terlebih dahulu dilakukan serangkain kegiatan penyelidikan yang dilakukan oleh Kepolisian Republik Indonesia khususnya oleh Reserse Kriminal (Dirdjosisworo, 1987: 28). Fungsi ini dalam organisasi kepolisian diemban oleh "fungsi reserse" yang khusus melaksanakan hukum dalam bidang represif yaitu melakukan segala tindakan sesudah terjadi kejahatan atau tindak pidana. Sehingga fungsi reserse atau penyidikan ini baru dilaksanakan setelah diketahuinya tindak pidana, baik melalui laporan, pengaduan, tertangkap tangan maupun diketahui langsung oleh penyidik.

Sebagai penyidik, polisi memiliki tugas dan wewenang khusus, yang diperlukan untuk kelancaran proses acara pidana, seperti yang telah ditentukan dalam UU No. 28 Tahun 1997 Tentang Kepolisian dan Pasal 6, Pasal 7, Pasal 14 dan Pasal 15 KUHAP (UU No. 8 Tahun 1981).

\section{METODE PENELITIAN}

Penelitian merupakan sarana pokok dalam pengembangan ilmu pengetahuan maupun teknologi. Hal ini disebabkan karena penelitian bertujuan untuk mengungkapkan kebenaran secara sistematis, metodologi dan konsisten. Melalui proses penelitian tersebut diadakan analisa dan konstruksi data yang telah dikumpulkan (Soekanto, 1986: 3).

Tipe penelitian yang digunakan dalam penyusunan tesis ini adalah yuridis normatif (legal research), yaitu penelitian yang difokuskan untuk mengkaji penerapan-penerapan kaidah atau norma-norma dalam hukum positif yang berlaku. Tipe penelitian yuridis normatif dilakukan dengan cara mengkaji berbagai aturan hukum yang bersifat formil seperti Undang-undang, peraturan-peraturan serta literatur yang berisi konsep-konsep teoritis yang kemudian dihubungkan dengan permasalahan yang akan dibahas dalam penelitian ini (Ibrahim, 2008: 295; Marzuki, 2010: 32).

Pendekatan yang digunakan dengan pendekatan undang-undang dan pendekatan konseptual. Sumber data yang digunakan dalam penelitian ini adalah data sekunder yang berupa bahan hukum primer, bahan hukum sekunder dan bahan hukum tersier.

\section{HASIL DAN PEMBAHASAN}

Faktor Peningkatan Tindak Pidana Curat dan Curas di Wilayah Hukum Polrestabes Medan

Perbuatan pidana yang sering terjadi ditengah masyarakat adalah pencurian. Perbuatan yang dilakukan oleh para pelaku pencurian menjadi salah satu perbuatan yang meresahkan masyarakat dan diperlukan penanganan yang cepat dan formula yang baik.

Pencurian sudah terjadi sebelum KUHP disahkan menjadi ketentuan hukum di Indonesia. Di dalam masyarakat yang beragama islam, perbuatan mencuri merupakan perbuatan yang dilarang oleh ajaran agama islam.

Menurut hukum positif Indonesia, perbuatan mencuri adalah perbuatan yang dilarang oleh undang-undang. Perbuatan tersebut dilarang untuk dilakukan karena dapat 
Hardiyanto, Marlina \& Muazzul, Peran Reserse Kriminal Umum sebagai Penyelidik Tindak Pidana...

membuat keadaan masyarakat menjadi tidak tertib, resah dan ketakutan. Hukum bertujuan untuk menciptakan ketertiban dan keamanan guna terwujudnya suatu masyarakat yang harmonis, damai dan tentram. Kedamaian dan ketentraman tersebut akan terwujud apabila seluruh komponen yang ada di dalam alam semesta ini patuh dan taat terhadap hukum yang berlaku. Seluruh alam semesta ini terikat dengan hokum agar keharmonisan, kedamaian dan ketentraman itu terpelihara dengan baik (Arief, 2001: 56).

Pengaturan mengenai perbuatan pencurian di dalam Kitab Undang-Undang Hukum Pidana, dibedakan dalam beberap klasifikasi pencurian, diantaranya:

1) Pencurian Biasa ( Pasal 362 KUHP)

2) Pencurian dengan Pemberatan (Pasal 363)

3) Pencurian Ringan (Pasal 364)

4) Pencurian dengan Kekerasan (Pasal 365)

Pencurian merupakan perbuatan pidana/tindak pidana yang ditujukan terhadap harta benda atau harta kekayaan seseorang. Tindak pidana pencurian adalah jenis tindak pidana yang paling sering terjadi di tengah-tengah kehidupan masyarakat. Meskipun tindak pidana ini bukan merupakan tindak pidana yang tergolong tindak pidana berat seperti pembunuhan, akan tetapi dapat menimbulkan keresahan dalam masyarakat khususnya yang berdiam atau bertempat tinggal di lingkungan tempat terjadinya pencurian.

Jumlah kejahatan konvensional seperti pencurian dengan pemberatan (curat), pencurian dengan kekerasan (curas) di Kota Medan, Sumatera Utara menurun selama tahun 2016 dan mengalami peningkatan di tahun 2017. Demikian dikatakan Kapolrestabes Medan, Komisaris Besar Polisi (Kombes Pol) Sandi Nugroho dalam keterangan pers akhir tahun di aula kamtibmas Mapolrestabes Medan, Sabtu (31/12/2016).

Kasus curat di tahun 2016 ada 1.434 kasus. Sedangkan di tahun 2015 mencapai 1.623 kasus, artinya ini turun hingga 189 kasus. Sementara kasus curas juga turun dari 619 kasus di tahun 2016 menjadi 437 di tahun 2016, turun 182 kasus, ditahun 2017 hingga bulan mei 2017 ini, ada mengalami peningkatan jumlah kasus 1.750 Kasus.

Rasa aman merupakan variabel yang sangat luas karena mencakup berbagai aspek dan dimensi, mulai dari dimensi politik, hukum, pertahanan, keamanan, sosial dan ekonomi. Sejalan dengan itu, statistik dan indikator yang biasa digunakan untuk mengukur rasa aman masyarakat merupakan indikator negatif, misalnya jumlah angka kejahatan (crime total), jumlah orang yang berisiko terkena tindak kejahatan (crime rate) setiap 100.000 penduduk. Semakin tinggi angka kriminalitas menunjukkan semakin banyak tindak kejahatan pada masyarakat yang merupakan indikasi bahwa masyarakat merasa semakin tidak aman. Upaya untuk memenuhi dan menciptakan rasa aman pada masyarakat merupakan langkah strategis yang turut mempengaruhi keberhasilan pembangunan nasional. Terciptanya dan terpenuhinya rasa aman pada masyarakat akan membangun suasana yang kondusif bagi masyarakat untuk melakukan berbagai aktifitas termasuk aktifitas ekonomi. Kondisi ini pada skala makro akan menciptakan stabilitas nasional yang merupakan salah satu prasyarat bagi tercapainya pembangunan dalam rangka mewujudkan masyarakat yang adil dan makmur. 
Beberapa kejahatan pencurian dengan pemberatan dan kekerasan pernah terjadi di Kota Medan, telah menjadi hal yang meresahkan masyarakat kota medan apalagi dilakukan dengan kekerasan terhadap korbannya. Terjadinya tindak pidana pencurian di Kota Medan dapat disebabkan karena beberapa faktor, yakni:

Faktor internal yang ditimbulkan dari dalam diri pelaku kejahatan, watak dan perilaku pelaku mempengaruhi perbuatan pelaku sehari-hari, dengan kata lain, keadaan psikis seorang pelaku kejahatan merupakan faktor terjadinya perbuatan pencurian.

Faktor eksternal yang berasal dari luar diri individu yang melakukan tindak pidana pencurian dengan pemberatan dan pencurian dengan kekerasan. Faktor eksternal ini juga berkaitan dengan hal yang diluar dari perkiraan si pelaku, misalnya faktor lingkungan, ekonomi, dan korban.

Keadaan lingkungan dari tempat tinggal pelaku kejahatan pencurian menjadi salah satu faktor yang mempengaruhi perbuatan atau tingkah laku pelaku sehari-hari. Lingkungan yang sehat dan tidak terpengaruh oleh obat-obatan terlarang dan lingkungan sehat baik secara ekonomi maupun geografis membuat seseorang akan enggan untuk melakukan pencurian akan tetapi sebaliknya, lingkungan yang dipengaruhi oleh obatobatan terlarang, kumuh dan tingkat ekonomi lemah akan membuat keadaan dari si pelaku untuk mudah melakukan pencurian.

Kondisi ekonomi pasti memiliki peran pada suatu terjadinya kejahatan, latar belakang ekonomi lebih terarah pengaruhnya terhadap kejahatan-kejahatan yang menyangkut harta benda seperti hal nya pencurian sepeda motor dengan kekerasan. Secara keseluruhan masyarakat Kota Medan dapat dikatakan telah mencapai kesejahteraan tetapi tidak benar-benar menyeluruh, sebagian besar masyarakat kecamatan di Kota Medan membuka usaha dan pegawai. Sebagian kecil bekerja sebagai buruh tani dan pedagang.

Korban adalah pihak yang dirugikan, sedangkan pihak pelaku merupakan pihak yang mengambil keuntungan. Kerugian yang sering diderita oleh korban biasanya adlaah korban fisik, mental, dan ekonomi (Herikson Parulian Siahaan, Marlina \& Muaz Zul, dkk, 2019).

Dalam hal kasus pencurian dengan pemberatan dan kekerasan sebagian besar disebabkan karena kesempatan yang didapat oleh si pelaku dikarenakan kelalaian dari korban dalam mengantisipasi terjadinya kejahatan, misalnya: kelalaian untuk menutup pintu rumah dilingkungan yang sunyi, tidak peduli dengan keadaan luar rumah dan selalu memamerkan kekayaan kepada lingkungan. Hal tersebut menjadi sesuatu penyebab terjadinya perbuatan pencurian di Kota Medan.

\section{Peran Reserse Kriminal Umum dalam Pemberantasan Tindak Pidana Curat dan Curas di Wilayah Hukum Polrestabes Medan}

Polrestabes Medan dalam menanggulangi tindak pidana pencurian dengan pemberatan dan pencurian dengan kekerasan mengedepankan Fungsi Reskrim untuk pelaksanaannya. Struktur organisasi Sat Reskrim Polresta Medan adalah sebagai berikut: Sat Reskrim di pimpin oleh seorang Kasat Reskrim, tugas Reskrim adalah sebagai berikut: 
Hardiyanto, Marlina \& Muazzul, Peran Reserse Kriminal Umum sebagai Penyelidik Tindak Pidana...

1) bertugas dan bertanggung jawab tentang segala sesuatu dalam lingkup pelaksanaan tugas satuan reserse;

2) melakukan tugas-tugas yang berhubungan dengan masalah-masalah perencanaan, pengorganisasian dan control terhadap tugas anggota;

3) melaksanakan koordinasi dengan kesatuan lain dan instansi samping;

4) melaksanakan supervisi staf;

5) mengendalikan tugas-tugas yang bersifat khusus terutama operasi yang dibebankan.

Menurut M. Faal, untuk melaksanakan tugas-tugas pokok, aparat kepolisian memiliki dua funsi utama yaitu: (1) Fungsi preventif untuk pencegahan, yang berarti bahwa aparat kepolisian itu berkewajiban melindungi negara beserta lembaga-lembaga nya, ketertiban dan ketahanan hukum, orang-orang dan harta bendanya, dengan jalan menceah dilakukan nya perbuata-perbuatan yang dapat dihukum dan perbuatan-perbuatan lain nya yang pada hakikat nya dapat mengancam dan membahayakan ketertiban dan ketentraman hokum; (2) Fungsi represif atau pengendalian, yang berati bahwa aparat kepolisian itu berkewajiban menyidik perkara-perkara tindak pidana, menangkap pelaku-pelakunya dan menyerahkannya kepada penyidikan untuk penghukuman (Faal, 1999: 43).

Berdasarkan hasil wawancara dengan Kasat Reskrim Polrestabes Medan, peran reserse umum kepolisian dalam mengatasi tindak pidana pencurian dengan pemberatan dan kekerasan adalah:

1) Melihat tingkat kejahatan dimana saja yang sering terjadi masalah pencurian, lalu pihak kepolisian melakukan patroli di wilayah yang rawan pencurian tersebut dan meningkatkan patroli sebanyak 2 sampai 3 kali untuk menekan tingkat kejahatan tersebut.

2) Melakukan penyelidikan dan penyidikan kepada pelaku kejahatan terhadap kelompok-kelompok yang bergabung dalam pencurian kendaraan bermotor.

3) Melakukan pengawasan kepada mantan narapidana yang pernah melakukan tindak pidana sebelumnya.

4) Melaksanakan kegiatan kring Serse dalam rangka penguasaan wilayah Potensi kerawanan kejahatan kususnya pencurian dengan kekerasan oleh Polres-Polres jajaran Polrestabes Medan sehingga dapat mempersempit Gerak pelaku kejahatan kususnya pencurian dengan pemberatan dan kekerasan.

5) Melakukan deteksi dini terhadap pelaku- pelaku kejahatan pencurian dengan pemberatan dan kekerasan dengan mengumpulkan sebanyak mungkin informasi dari informan dan melakukan pencatatan / identifikasi pelaku- pelaku kejahatan pencurian dengan kekerasan termasuk kelompok dan sindikatnya (Wawancara dengan Kombes Fahrizal SIK, Kasat Reskrim Polrestabes Medan, 29 April 2017).

Polrestabes Kota Medan dalam tindakan/menanggulangi pencurian dengan pemberatan dan pencurian dengan kekerasan maka wilayah hukum polrestabes Medan telah melakukan suatu kebijakan Dengan melihat pekembangan masyarakat dan kejahatan yang semakin kompleks, maka Polrestabes Medan, khususnya Satuan Reskrim, telah melakukan perubahan guna peningkatan pengungkapan perkara pidana agar lebih terfokus dan memiliki kemampuan, ketrampilan dan keahlian sesuai dengan pembidangan tugasnya (kebijakan hukum dalam mengalokasi peranan Polri dalam 
menangulangi Pencurian dengan pemberatan dan pencurian dengan kekerasan), maka dibentuklah unit-unit spesialisasi terhadap penanganan perkara pidana tersebut oleh unit-unit yang di sesuaikan dengan karateristik wilayahnya, yaitu:

1) Unit yang menangani Kejahatan transnational, yaitu penanganan terhadap kejahatan terrorisme, illictit drug trafficking, Arms Smugling, Sea Pracy, Money loundrng, Trafficking in Person, Cyber crime, dan International economic Crime;

2) Unit yang menangani Kejahatan Konvensional, yaitu kejahatan yang melanggar KUHP yang belaku, atas perbuatan yang meliputi Kejahatan terhadap manusia, kejahatan terhadap harta benda, dan kejahatan terhadap masyarakat;

3) Kejahatan terhadap Kekayaan Negara, yaitu kejahatan yang berdampak kepada negara yang dilakukan oleh perorangan atau bersama-sama (suatu badan), meliputi Korupsi (Keuangan Negara), Illegal logging, illegal Fishing, Lingkungan hidup dan Fasilitas Umum (PLN, Telkom, HAKI dan Ketenaga kerjaan);

4) Unit yang Menangani Kejahatan yang berimplikasi Kontijensi,yaitu kejahatan yang dapat mempengaruhi kemungkinan terjadinya hal-hal yang mengganggu keamanan, Situasi politik, ekonomi, dan keresahan masyarakat, yang meliputi Keamanan Negara, Konflik SARA dan Kasus unjuk rasa anarkis (Wawancara dengan Kombes Fahrizal SIK, Kasat Reskrim Polrestabes Medan, 29 April 2017).

Penanganan perkara oleh unit-unit berdasarkan pengelompokan jenis kejahatan, merupakan faktor yang menuntut adanya perobahan dalam struktur suatu organisasi, Sedangkan kekuatan personil unit, di sesuaikan dengan beban tugas sesuai dengan spesialisasi penanganan perkara (penggolongan perkara) dan karateristik kerawanan daerah. Agar kegiatan penyidikan pada unit lebih terfokus, maka pada setiap unit dalam melaksanakan kegiatan penyidikan dibagi menjadi dua fungsi yang saling terkait yaitu Pelaksana fungsi penyidikan dan penyelidikan, dimana kedua fungsi tersebut saling melengkapi dalam pengungkapan perkara hingga penyelesaian perkara (Wawancara dengan Kombes Fahrizal SIK, Kasat Reskrim Polrestabes Medan, 29 April 2017).

Tindakan kepolisian Resort Kota Medan dalam menangani tindak pidana pencurian dengan kekerasaan yang digunakan sebagai dasar hukum positif adalah KUHP, KUHAP, Undang-undang No. 2 tahun 2002 tentang Kepolisian Negara Republik Indonesia serta peraturan perundang-undangan dan norma etika dalam masyarkaat yang ada kaitannya dengan peristiwa yang terjadi (modus operandi).

\section{Hambatan yang Dihadapi oleh Reserse Kriminal Umum dalam Penanganan Tindak Pidana Curat dan Curas di Wilayah Hukum Polrestabes Medan}

Hambatan yuridis yaitu Penerapan Pasal 363 dan Pasal Pasal 365 Kitab Undang Undang Hukum Pidana pada praktiknya sering kali dalam putusan hakim tidak diberikan putusan maksimal, hakim sering kali mempertimbangkan keringan terhadap perilaku terdakwa sehingga putusan hakim biasanya dibawah tuntutan jaksa penuntut umum. Pasal 363 dan Pasal 365 saat ini sudah menjadi pasal yang harus dilakukan perubahan karena modus dari kejahatan pencurian sudah mulai berkembang dan sulit untuk dilakukan penyidikan, maka untuk itu, aturan hukum tersebut perlu mendapat revisi sesuai dengan perkembangan hukum dimasyarakat, agar kepastian dan keadilan dalam masyarakat dapat tercapai. 
Hardiyanto, Marlina \& Muazzul, Peran Reserse Kriminal Umum sebagai Penyelidik Tindak Pidana...

Hambatan non yuridis yang menjadi kendala bagi kinerja penegakan hukum terhadap tindak pidana Pencurian dengan pemberatan dan kekerasan adalah berkaitan dengan persoalan struktur hukum dan kultur hukum, yang meliputi: (1) Lemahnya Koordinasi antar Penegak Hukum; (2) Kultur masyarakat; (3) Keterbatasan Personel Kepolisian; (4) Tingkat ekonomi mayarakat yang tidak merata; (5) Besarnya Urbanisasi yang masuk di Kota Medan

Lemahnya koordinasi antar instansi penegak hukum dapat merumbulkan tumpang tindih kewenangan dan kebijakan masing-masing, sehingga sangat rawan menimbulkan konflik kepentingan. Misalnya saja pada Kasus Pencurian dengan Pemberatan tersangka gaga, dimana kejaksaan memulangkan berkas penyidikan tanpa alasan hukum yang jelas.

Penegakan hukum yang tidak terkoordinasi merupakan salah satu kendala dalam penegakan tindak pidana pencurian dengan pemberatan dan kekerasan. Proses peradilan mulai dari penyelidikan hingga ke persidangan membutuhkan biaya yang sangat besar. (Iskandar Muda Sipayung, Tan Kamello, Marlina , Arie Kartika., dkk 2019). Dalam satu instansi tentu tidak memiliki semua komponen, data/informasi ataupun sarana dan prasarana yang dibutuhkan dalam rangka penegakan hukum. Oleh karena itu diperlukan koordinasi dan kerjasama yang sinergis antar instansi yang terkait dalam upaya penegakan hukum terhadap tindak pidana pencurian dengan pemberatan dan pencurian dengan kekerasan.

Kota Medan sebagai kota metropolitan dengan penduduk yang heterogen dari berbagai suku, etnis dan agama menjadi salah satu kelemahan bahwa ditengah masyarkat kota medan yang metropolitan, kepedulian terhadap lingkungan sekitar tidak begitu besar, masyarakat pada umumnya sibuk dengan urusan masing-masing. Pemukiman dengan tinggal di perumahan-perumahan yang terkelompok-kelompok menjadikan massyarakat kota medan tidak saling bersosialisasi dengan kelompok diluar kelompok kompleks perumahanya saja, dan sebatas rekan kerja atau saudara dekat,sehingga nilainilai kearifan lokal tidak lagi tertanam dan terlaksana di tengah masyarakat kota medan. Kenyataan tersebut menjadikan hambatan dalam melakukan pencegahan terjadinya kejahatan pencurian karena masing-masing masyarakat tidak peduli dengan lingkungan, hal tersebut memudahkan pelaku kejahatan melakukan aksinya. Oleh karena itu, penting kiranya untuk menumbukan kembali semangat dan rasa kekeluargaan ditengah kehidupan metropolitan Kota Medan agar pelaku-pelaku kejahatan merasa kesulitan untuk melakukan aksinya yang pada akhirnya akan mengurangi dan mencegah terjadinya tidak pidan pencurian.

Terbatasnya personel Kepolisian di setiap Resort Kecamtan dan kelurahan di Kota Medan menjadikan fungsi pengawasan dan pelayanan publik masyarakat oleh polri menjadi terhambat. Polri tidak dapat menjalankan dengan maksimal dan optimal tugas dan fungsinya ditengah masyarakat. Oleh karena itu, penambanhan anggota POLRI yang ditempatkan di setiap Resort Kecamatan dan Kelurahan akan mempersempit ruang gerak pelaku kejahatan. Selain itu, diperlukan juga penambahan personel anggota pada Unit Reskrim khususnya di Polrestabes Kota Medan agar dapat melaksanakan fungsi penyidikan dengan maksimal, optimal dan profesional. 
Salah satu penyebab utama kejahatan adalah faktor ekonomi, kota medan sebagai salah satu kota metropolitan di Indonesia, secara garis besar masyarakat nya sudah berada pada tingkatan masyarakat yang memiliki ekonomi menengah, akan tetapi tidak dipungkiri masih banyak masyarakat yang berada pada tingkat ekonomi lemah. Berdasarkan kenyataan tersebut, peran pemerintah daerah untuk melakukan langkah strategis guna meningkatkan kesejahteraan masyarakat agar masyarakat mampu bekerja dan berpenghasilan sehingga pencegahan terhadap perilaku kejahatan dapat dilakukan.

Secara geografis kota Medan terletak berbatasan dengan beberapa daerah kabupaten dan kota di sumatera utara sehingga menyebabkan orang-orang yang berada dari luar kota medan sangat mudah untuk datang, menetap dan bertempat tinggal di kota medan. Besarnya tingkat urbanisasi dari daerah lain ke kota medan menjadi salah satu pemicu terjadinya perilaku kejahatan dan menjadi penghambat bagi para penegak hukum untuk melakukan penyidikan karena para pelaku kejahatan terkadang memiliki identitas ganda terhadap domisilinya.

Hambatan yuridis dan non yuridis tersebut merupakan sebuah tantangan dan pekerjaan rumah bagi pemerintah, lembaga penegak hukum dan masyarakat untuk dapat mengatasinya secara berasama-sama. Penegakan hukum pidana tidak dapat hanya dilakukan sepenuhnya oleh lembaga penegak hukum semata, prisinsip dasar sistem peradilan pidana adalah keterlibatan semua sub sub sistem peradilan pidana, diantaranya Kepolisian, Kejaksaan, pengadilan dan lembaga pemasyarakatan ditambah dengan pemerintah dan masyarakat sebagai pendukung terlaksananya atau terwujudnya sistem peradilan pidana yang baik ditengah penegakan hukum khsusunya terhadap kasus pencurian dengan pemberatan dan kekerasan di wilayah hukum Polrestabes Kota Medan.

\section{SIMPULAN}

Faktor Penyebab Terjadinya Tindak Pidana Pencurian dengan Pemberatan dan Tindak Pidana Pencurian dengan Kekerasan di Kota Medan dapat dibedakan menjadi Faktor internal dan faktor eksternal. Faktor Internal merupakan faktor yang terdapat pada diri pelaku kejahatan secara individu yakni kepribadian dari seseorang sedangkan Faktor eksternal ini berasal dari luar diri individu yang melakukan tindak pidana pencurian dengan pemberatan dan pencurian dengan kekerasan, Faktor Lingkungan Faktor Ekonomi serta Faktor Korban. Faktor penyebab seseorang melakukan pencurian baik dengan pemberatan atau kekerasan tidak hanya di pengaruhi oleh beberapa faktor tapi kesemuanya faktor tersebut saling mempengaruhi satu sama lainnya. Situasi kepribadian si pelaku di konversikan dengan keadaan luar diri pelaku menjadi satu kenyataan bahwa terjadinya tindak pidana pencurian dengan pemberatan dan kekerasan di kota Medan terjadi karena kompleksitas faktor penyebab terjadinya kejahatan

Peran Reserse Kriminal Umum dalam mengatasi penanggulangan Tindak pidana pencurian dengan pemberatan dan kekerasan adalah sebagai bagian dari lembaga kepolisian yang berperan untuk melakukan penyelidikan dan penyidikan sebuah tindak pidana khusunys tindak pidana pencurian dengan pemberatan dan kekerasan. Bagian Reserse Kriminal umum menjadi ujung tombak bagi lembaga kepolisian untuk 
Hardiyanto, Marlina \& Muazzul, Peran Reserse Kriminal Umum sebagai Penyelidik Tindak Pidana...

mendapatkan titik terang sebuah peristiwa pidana dan penangkapan dari tersangka tindak pidana.

Hambatan dalam penegakan hukum tindak pidana pencurian dengan pemberatan dan kekerasan digolongkan menjadi dua yakni Hambatan yuridis dan non yuridis. Hambatan Yuridis dilihat dari aspek peraturan perundang-undangan yang berlaku terkait dengan penerapan hukum tindak pidana pencurian dengan pemberatan dan kekerasan, sedangkan hambatan Non yuridis dilihat dari luar aspek hukum, misalnya aspek Lemahnya Koordinasi antar Penegak Hukum, Kultur masyarakat, Keterbatasan Personel Kepolisian, Tingkat Ekonomi mayarakat yang tidak merata serta Besarnya Urbanisasi yang masuk di Kota Medan

\section{DAFTAR PUSTAKA}

Anas, A., \& Marlina, M. (2018). Analisa Yuridis Penyidikan Tindak Pidana Illegal Logging oleh Polres Tapanuli Tengah. JURNAL MERCATORIA, 11(1), 61-73. doi:https://doi.org/10.31289/mercatoria.v11i1.1602

Arief, B.N. (2001). Masalah Penegakan Hukum dan Kebijakan Penanggulangan Kejahatan. Bandung: Citra Aditya Bakti.

Dirdjosisworo, S. (1987). Ruang Lingkup Kriminologi. Bandung: Remaja Karya.

Faal, M. (1999). Penyaringan Perkara Pidana oleh Polisi (Diskresi Kepolisian). Jakarta: Pradnya Paramita.

Fadhlurrahman, Rafiqi \& Kartika, A. (2019). Proses Penyidikan Dalam Penyelesaian Tindak Pidana Kekerasan Dalam Rumah Tangga Yang Dilakukan Oleh TNI-AD (Studi Di Pengadilan Militer I-02 Medan). JUNCTO, 1(1) 2019: 52-64,

Faidir, dan Marlina, (2012), Peran Polri dalam Proses Penyidikan Tindak Pidana terhadap Anak Yang Berkonflik dengan Hukum, Mercatoria, 5 (1): 12-22

Herikson Parulian Siahaan, Marlina \& Muaz Zul. (2019). Peran Kepolisian dalam Penyidikan Tindak Pidana Korupsi (Studi pada Kepolisian Daerah Sumatera Utara). ARBITER: Jurnal Ilmiah Magister Hukum.1(2): 135-145.

Ibrahim, J. (2008). Teori dan Metodologi Penelitian Hukum Normatif. Surabaya: Bayumedia.

Iskandar Muda Sipayung, Tan Kamello, Marlina \& Arie Kartika. (2019). Perjanjian Jaminan Fidusia Kaitan dengan Penyidikan Tindak Pidana Perlindungan Konsumen. ARBITER: Jurnal Ilmiah Magister Hukum. 1(2): 157-166.

Julimaster Saragih, Marlina \& Muaz zul. (2019). Penyidikan Terhadap Tindak Pidana Penyalahgunaan Izin Lokasi. ARBITER: Jurnal Ilmiah Magister Hukum, 1(1) 2019: 11-18.

Kitab Undang-Undang Hukum Acara Pidana

Kitab Undang-Undang Hukum Pidana

Marmosudjono, S. (1989). Penegak Hukum di Negara Pancasila. Jakarta: Pustaka Kartini.

Marzuki, P. M. (2010). Penelitian Hukum. Jakarta: Kencana Persada Group.

Muladi \& Arief, B. N. (1984). Teori-teori dan Kebijakan Pidana. Bandung: Alumni.

Peraturan Perundang-undangan:

Simanjuntak, M., Januari S., dan Isnaini, (2010), Peran Polri dalam Penyidikan Tindak Pidana Kekerasan Seksual dalam Rumah Tangga (Studi di Unit Perlindungan Perempuan dan Anak Sat Reskrim Polresta Tebing Tinggi), Mercatoria, 3 (2):102-116

Sirait, B., \& Sahari, A. (2014). PERANAN POLISI MILITER ANGKATAN UDARA DI DALAM PENYIDIKAN KASUS NARKOBA DALAM WILAYAH HUKUM LANUD SOEWONDO (MEDAN). JURNAL MERCATORIA, 7(1), 3045. doi:https://doi.org/10.31289/mercatoria.v7i1.658

Soekanto, Soerjono. (1986). Pengantar Penelitian Hukum. Jakarta: UI Press.

Tribun News. (2015). Kasus Curas Curanmor dan Narkoba Tertinggi di Sumut Selama 2015. Retrieved from http://medan.tribunnews.com/2015/07/24/kasus-curas-curanmor-dan-narkoba-tertinggi-di-sumutselama-2015.

Undang-Undang Dasar Negara Republik Indonesia tahun 1945

Undang-Undang Nomor 2 tahun 2002 tentang Kepolisian Negara Republik Indonesia 